\title{
The Effects of Using Yell Video on the Third Semester Students' Grammar Ability at the Business English Study Program of the State Polytechnic of Bengkalis
}

\author{
Aprizawati, Diah Paramita Sari, and Safra Apriani Zahraa \\ English Business Study Program \\ The State of Polytechnic of Bengkalis \\ aprizawati@polbeng.ac.id, diah@polbeng.ac.id, \\ sapra@polbeng.ac.id
}

\begin{abstract}
An English aspect that contains materials and formulas to be memorized is grammar. One of materials is tenses. Those discuss about structure and form of sentences engaging to the time (present, past, future). Mastering them is not easy for most students because they will get easily bored.They always face difficulties in learningthe formulas and structure of the sentences. Therefore, they were given a technique to help them learn tenses is by using yell videos. The purpose of the study was to find out whether the use of Yell Videos gives significant effect tothe students' ability in learning tenses at State Polytechnic of Bengkalis. The study of the research was a quasi-experimental research in which pretest and posttest design were given in this research. The sample of this research was the fifth semester students of English Study Program at State Polytechnic of Bengkalis. They were experimental class $(5 B)$ and control class $(5 A)$ with the total samples 50 students. The data were collected by using yell videos in learning tenses. Yell videos were used in this research.The result of this research showed that there was a significant effect of using Yell Videos on students' learning tenses for Experimental Group. It could be seen that students' who were taught by Yell Videos had better grammar ability in learning tenses than students' who were taught by conventional teaching.
\end{abstract}

Key Words-Yell Videos, tenses, grammar

\section{INTRODUCTION}

English is widely used in various fields, such as social, economy, information and technology, etcetera. For examples, an entrepreneur who is good in English can be successfully involved in trade or business worldwide. In other words, she or he will have good career and compete in international world. In addition, the mastery of English either in oral or written form can help people get updated information and technology that is important for nowadays' living. Therefore, it can be said that English is very important to be mastered for everyone.

English is learned formally from elementary school to university level in Indonesia. Meanwhile, learners can also learn it in courses offered for those who want to improve their English. However, the learners still face difficulties in learning and mastering it, including the students of higher education. One of common difficulties that the students face is learning and understanding the grammar.

An English aspect that contains materials and formulas to be memorized is grammar. One of materials is tenses. Those are studies about the structure and form of sentences engaging to the time (present, past, future). Learning them needs a lot of practice because students will get easily bored. In addition, mastering formulas is not easy for them because of less motivation. As a consequence, they always face difficulties in learning grammar especially tenses.(Safra:2016)

There are many difficulties in learning which might occur because of the learning method uses; one of them is still using the traditional way. The learning method always makes students be bored in other case the lecturer as the center and the one who speaks the most. Therefore, there are various ways in learning English that will help the students understand it. Yell video is one of the most popular and effective ways. 
The video shows students who perform yell that contain sentences using every types of tenses.

YELL

\section{THEORETICAL FRAMEWORK}

In Indonesian Language, yell is known as "yel-yel" which means "teriakan". According to Supriadi in Sunarto (2012), yell is one of activities in Icebreaking technique which means ice. It is often used in training so they know each other, understand and can interact to each other. Besides yell, parts of icebreaking activities are song, mime, clap hands technique, etc. Solihan (2011) stated that yell contains shout with motivation words. One of technique that can be used in teaching and learning process is yell. This technique can create an enjoyable atmosphere especially when students learn tenses which are known complicated materials because they are full of formula and rules. Puji in Safra (2016) said that teachers can modify certain songs become yell containing motivation words. They can be performed before learning begins. According to her, they are two kinds of yell. 1) Classroom yell. It is performed to set the condition of learning readiness. 2) Lesson yell. It contains words to motivate students to learn lesson.

There are some purposes of yell. They are: 1) to build learning motivation. 2) To create fun atmosphere in learning. 3) To build good and friendly relationship between teachers and students.

\section{YELL VIDEO}

Students like to learn English by using an interesting medium, one of the media is by using video. Video can make students interested in learning. The use of video can create enjoyable atmosphere and avoid boredom in teaching and learning process. If the video contains English materials that are modified with interesting ways, the learning process becomes more fun. Yell videos were created to help the students learn tenses in enjoyable ways.

\section{TENSES}

Tenses discuss about time. Each time has different formulas used. That is why it is important to memorize the formulas of tenses in order to minimize errors in stating an action. Azar (2006) states that there are twelve common tenses used in English.

They are:

1. Simple present

It is used to state actions in the presents, habits, or general truth.

Nominal form (no verb)

For example: I am busy

Verbal form (uses verb)

For example: We go to cinema every week

2. Present progressive

It is used to state that an action has started, but it has not finished yet. It is happening now and we are in the middle of it.

For example: They are playing volleyball

3. Present perfect

It is used to state an action in a period leading up to the present, a series of actions before now, and an event lasting up to the present.

Nominal form

For example:YongDolah has been in Bangkok

Verbal form

For example: She has taken abath

4. Present Perfect Progressive

It is used for an action over a period of time leading up to the present.

For example:Miley Cirrus has been singing for five years

5. Simple past 
It is used for an action in the past.

Nominal form

For example: He was happy yesterday

Verbal form

For example: My mother went to Batam last week.

6. Past progressive

It is used to express the idea that at a time in the past we were in the middle of something when another action took place,

For example: I was teaching English when John came

7. Past perfect

It is used to state that an action had finished when another action occurred in the past.

Nominal form

For example: I had been in office before Sue came

Verbal form

For example:Milla had left after his friend arrived

8. Past perfect progressive

It is used for an action that went on over a period when another action occurred in the past time.

For example:You had been teaching English when the headmaster came

9. Simple future

It states that an action will take place in the future.

Nominal form

For example: Jack will be in America next week

Verbal form

For example: We will buy Grammar Book tomorrow

10. Future progressive

It is used for an action that will be in the middle of when another action occurs in the future.

For example: He will be playing a piano

11. Future perfect

It is used to state that an action is finished in the future when another action happens.

For example: He will have arrived at 9 a.m

12. Future perfect progressive.

It is used to state that an action has started and still in progress when another action happens in the future.

For example: Amanda will have been repairing his car at the garage.

\section{Methodology}

In this research, Quasi-Experimental research was used. According to Cresswell(2008: 299), it is used to test an idea (or practice or procedure) to determine whether it is influenced an outcome or dependent variable. An experiment is the quantitative approach that provides the greatest degree of control over the research procedures (L.R Gay, 2000: 15). This research used quasiexperimental design with nonequivalent control group which was an appropriate one to this research in order to find out the significant effect of using yell videos to learn tenses of students at State Polytechnic of Bengkalis.

In this research, there were two classes; one class is an experimental group which was treated by using the Yell Videos and another one is as a control group taught by using non Yell Videos. For both experimental and control groups, pre-test and posttest administered to the students. Pre-test was given at the beginning of the teaching learning in order to identify the students' English in learning tenses. Then, the experimental group was given a treatment by using Yell Videos and the control group using non Yell Video. During the treatment, the writer accompanied by an observer, and at last, both groups was given post-test at the end of the teaching learning processes in order to determine the effect of using yell videos to learn tenses of students at State Polytechnic of Bengkalis. The model of the research design is illustrated in the table 1 below.

Table 1. The Research Design

\begin{tabular}{|c|c|c|c|}
\hline Group & Pre-test & Treatment & Post-test \\
\hline Experimental group & Test 1 & $\mathrm{X}$ & Test 2 \\
\hline Control Group & Test 1 & - & Test 2 \\
\hline
\end{tabular}


IV. FINDING AND DISCUSSION

In order to know the effect of using yell video, the data was analyzed by using t-test formula. The researcher used Lilliefors testing for analyzing the normality testing at the level of significance 0.05 . Variance Formula was used to test homogeneity testing. The data analysis can be seen from the table 2 below:

Table 2. Result of t-test for experimental and control group

\begin{tabular}{|c|c|c|c|c|c|}
\hline & N & Mean & Std.Deviation & Minimum & Maximum \\
\hline Experimental & 26 & 73.35 & 4.995 & 67 & 83 \\
\hline Control & 26 & 59.58 & 3.826 & 50 & 68 \\
\hline
\end{tabular}

The table shows that the total students from each group was 26, the mean score of experimental group was 72.92, and mean score of control group was 59.58. Standard deviation from experimental group was 4.995, while standard deviation from control group was 3.826. From the output above, it also can be seen that $\mathrm{t}_{\text {observed }}=2.09$ compared to $\mathrm{t}_{\text {table. }}$. The level of significances 0.05 was 1.708 . It can be concluded that $2.09>1.708$ $\left(t_{\text {observed }}>t_{\text {table }}\right)$. Therefore, null hypothesis $\left(\mathrm{H}_{\mathrm{o}}\right)$ was rejected, while the alternative hypothesis $\left(\mathrm{H}_{\mathrm{a}}\right)$ was accepted. It means there was a significant effect of using yell video on students' grammar ability.

This finding was line with Supriadi in Sunarto (2012) statement that yell was one of activities in Icebreaking technique which means ice. It is often used in training so they know each other, understand and can interact to each other. Besides yell, parts of icebreaking activities are song, mime, clap hands technique, etc. Solihan (2011) stated that yell contains shout with motivation words. One of technique that can be used in teaching and learning process is yells. This technique can create an enjoyable atmosphere especially when students learn tenses which are known complicated materials because they are full of formula and rules.

\section{CONCLUSION}

This research was done at the third semester students of State Polytechnic of Bengkalis, From the result, it can be concluded students' who were taught by Yell Video had better grammar ability in learning tenses than students' who were taught by Conventional Teaching. Students' mean score of experimental class (73.35) who were taught by Yell Video was higher than students in control class (59.58) who were taught by conventional teaching. Yell Video is a good alternative to help students in learning tenses. This techniquecan makes students interested in learning English especially grammar. It is suggested that this technique can be applied by English lecturer.

\section{References}

Aprizawati, Zahraa,Safra A. (2016). The making of yell videos to learn tenses.P3M: SNIT POLBENG.

Astuti, Puji. (2011). The effectiveness of course review horray in Improving students'simple past tense mastery (an experimental study) at grade XI of SMA Negeri 1 Subah. English Department Faculty of Languages andArts.Thesis.Semarang State University.

Azar, B.S., Hagen, S.A. (2006). Understanding and Using English Grammar.Second Edition. New York: Pearson Education

Creswell, John. W. (2008). Educational Research: Planning, Conducting, and Evaluating Quantitative and Qualitative Research Ed $3^{\text {rd }}$. Lincoln: Pearson Education International.

Gall and Borg. (2003).Educational research: an introduction. London: Pearson Education.

Jasmansyah(2008).ejournal.undiksha.ac.id/index.php/JJPGSD/article/viewFile/1341/1202. Retrieved on August 20 th, 2016

L. R. Gay and Peter Airasian. (2000). Educational Research Competencies for Analysis and Application

Sixth Edition. New Jersey: Pearson Education

Pujiyanti(2013)ejournal.undiksha.ac.id/index.php/JJPGSD/article/viewFile/1341/1202. Retrieved on August 20th, 2016

Solihan.(2010).AplikasiYelYelMotivasiSebagaiStrategiReenforcementdalamMeningkatkanMotivasiBelajar

PAI Siswa di SMA Muhammadiyah 2Sidoarjo.Skripsi.IAINSunanAmpel

Sunarto.(2012). Icebreaker dalamPembelajaranAktif. Surakarta: Cakrawala Media. 